\title{
EDUCATION FROM THE PERSPECTIVE OF ISLAMIC AND WESTERN SCIENTISTS (CASE STUDY: GHAZALI AND PLATO)
}

\author{
Jahanbakhsh Orak \\ Department of Education, Izeh branch, Islamic Azad University, Iran
}

\begin{abstract}
Philosophy of education deals with study and processes of the aims and nature of the programs and the results of education. Although education and cultivation are two different terms and have two different concepts, they are inseparable in practice. In this study, education was studied from view of two scientists, Ghazali and Plato. Ghazali viewed childhood as being very important and believed that this period should be used as opportunities to teach because what child learns at this time much influence his future. By scientific illumination and as a great coach of Islamic training, Ghazali caused great change through the religious orientation in education and establishing principles, goals and educational methods. One of the great philosophers is Plato, the father of the philosophy of the West. The results indicated that Plato considered educational objectives to include physical goals, talentrelated goals as well as moral, intellectual and social goals. Platonic curriculum include habituating children to play, physical education, teaching reading and writing, training, and teaching philosophy and dialectics and literature. According to Plato, the best teaching method is one that focuses on conversation.
\end{abstract}

Keywords: education, Islam, the West, Ghazali, Plato, divine development

\section{İSLAM VE BATI BİLIM AÇISINDAN EĞITIM (ÖRNEK OLAY: GAZALI VE PLATO)}

\section{$\ddot{O Z Z}$}

Eğitim Felsefesi çalışmasında amaç ve programların doğası ve eğitim sonuçlarının süreçleri ile ilgilenir. eğitim ve yetiştirme iki farklı terimlerdir ve iki farklı kavram olmasına rağmen, pratikte ayrılamaz. Bu çalışmada, eğitim iki bilim adamı, Gazali ve Platon görünümünden çalışılmıştır. Gazali çok önemli olarak çocukluğunu inceledi ve bu süre hangi çocuk çok onun geleceği etkileyen şu anda öğrenir çünkü firsatlar öğretmek için kullanılır gerektiğine inanıyordu. Bilimsel aydınlatma ile ve İslami eğitim büyük bir koç olarak, Gazali, eğitim ve kuran ilkeleri, hedefleri ve eğitim yöntemlerinin dini yönelim sayesinde büyük bir değiş̧iklik yarattı. Büyük filozofların biri Platon, Batı felsefesinin babasıdır. Sonuçlar Plato fiziksel hedefleri, yetenek ile ilgili hedefleri yanı sıra, ahlaki, entelektüel ve sosyal hedefleri kapsayacak şekilde eğitim hedeflerini dikkate belirtti. Platonik müfredat oynamak için çocukları, beden eğitimi, öğretimi okuma ve yazma, eğitim ve öğretim felsefesi ve diyalektik ve edebiyat alıştırmak içerir. Platon'a göre, en iyi öğretim yöntemi konuşma üzerinde duruluyor biridir.

Anahtar Kelimeler: eğitim, İslam, Batı, Gazali, Platon, ilahi gelişme

\section{INTRODUCTION}

Philosophy is the method of correct thinking, ways of wise living and trying to understand the universe. We have a diverse range of philosophy including the philosophy of religion, philosophy of art, philosophy of science, and the philosophy of education. Education philosophy holds that traditional perceptions of philosophy is not enough to meet the psycho-educational realities of life of people in the current era. Also, this paper aimed to say that we need a systematic philosophical thinking and correct thinking and in education and lifestyle and that we can teach it even to children 
and young students, if the subject is suitable, language is appropriate, and the right tools and the proper circumstances for these teachings are used.

Philosophy of education deals with study and processes of the aims and nature of the programs and the results of education. These studies can occur in the context of education as a socio-cultural institution or in a broader sense as the process of existential growth of the human, namely the manner of change of human understanding of the world (e.g., understanding of objective reality, social habits, history, culture and even our emotions). With the help of the philosophy of education, education can be made meaningful in the areas ofaction and theory. So, the philosophy of education is a theoretical knowledge "to act

wisely in the way of training and thinking about it goals and results" to introduce the fundamentals of true education in a coherent and consistent manner and avoid contradictions in the theory and practice of education (Ebrahimzadeh, 2004: 65). In another definition, (Paksrsht, 1380, p. 5) it is said that the philosophy of education is a theoretical activity about the education's process, goals, purpose, methods and results and achievements.

\section{CONCEPTUALIZATION \\ TRAINING}

Training is an action for the purpose of the training. Usually what the teacher does to facilitate the learning activities of learners are performed with or without the the help of educational materials (Saif, 2005). Training is in fact an attempt by teachers to bring their students to take specific knowledge and mainly depends on the expertise of the teacher and the curriculum.

\section{EDUCATION}

Education and training are sometimes used interchangeably (Saif, 2005: 28). However, these can be very different. Training means the activity aimed at development of insight, knowledge and behavioral patterns required for fulfilment of a specific task or assignment (Saif, 2005: 28); or two create expertise through practice and some believe that training applies to both the human and the animal, such training horses, while education may not apply to animals, for instance, it is meaningless to say one educates a horse (Naghibzadeh, 2009).

\section{EDUCATION ACCORDING TO ISLAM}

In the analysis of the definition of "education", it was concluded education and training are inseparable, realization of one is not possible without that of another. Now we should see how see the relation of these two? In the Qur'an and Hadith, how is the relationship between them depicted?

Although education and cultivation are two different terms and have two different concepts, they are inseparable in practice. Some exegetics have noted some points:

1. In tafsir nimunah, precedence and subsequence of them is noted, "This shows that they are interactive (ethics (education) is product of science and vice versa"(Makarem Shirazi, 1983: 17).

2. Writer of al-mizan noted under the second verse of Sura Friday that cultivation is superior over education and stresses such precedence: "It is clear that in the universe, realization of science precedes cultivation, because the latter realizes through practice and ethics. So first, you need to obtain knowledge of competent and virtuous deeds, and then to practice them, to obtain gradually Zakat (purity of heart)" (Tabatabai, 1984: 19, 447).

\section{GHAZALI'S VIEW OF EDUCATION}

Ghazali also treatises about the education such as letter to children that is originally Persian and called Ayuha al-walad, and in addition to this, his other works such as The alchemy of happiness and Ayuha al-ulum are devoted to this issue. Among early philosophers, the only author and scientist to fully pay attention to the education and the research Ghazali (Homaei, 1963: 397-398). In fact, Ghazali is among the earliest scientists that focused on education, especially child education and devoted his book Ihya al-ulum al-din, The alchemy of happiness, as well as Ayuha al-walad and Ayuha al-ulum to this important topic.1993: 301). 
Ghazali considered positive and negative aspects for education and said that heart must be emptied of bad morals and filled with good morals (seminary school-university cooperation office, 1993: 301). It is seen from study of his work that he didn't provide an independent definition of education and group of terms he used rather apply to plants and physical development of child; however, by way of combination and rather indulgently, from his use of such terms of education, purification and austerity, his definition of education can be obtained as follows: mentor must empty the pupil of bad morals and fill him with good morals and this is what education is all about (Attaran, 1987: 63).

\section{OBJECTIVES OF EDUCATION}

Perfection is the goal of every being and its creation and, accordingly, the purpose of education is perfection. Therefore, the aim of human education is to facilitate the course of the ascent of man towards perfection in his creation. Ghazali wrote difference between man and animal is reason, by which to reach and know the god, and obtain wisdom and by which to rid himself of lust and wrath (Topping, 1994: 27, 28).

In terms of training human, Ghazali's following statement makes the issue quite clear: the nature will not be good unless four following faculties work well: faculties of science, anger, lust and Justice; of these three, the first shall distinguish between good and evil in the deeds and lie and truth in the words; the second shall be under command of wisdom and sharia; the third shall be ruled by reason and the last shall be ruled by religion and reason to control lust and anger (Ghazali, 1992: 15). He considered the education to be the way of development of the human soul leading ultimately to the truth and proximity with the God (group authors, 1993: 295).

\section{PRINCIPLES OF EDUCATION}

Ghazali's educational principles are:

1. The role taking of baby's heart; 2 . Changing nature of ethics; 3 . Principle of graduation in shaping of character; 4. The role of habit in education; 5 . The role of induction in education; 6. Negative and positive nature of education; 7 . There are differences between people; 8 . There are multiple steps and principles of each must be observed (group authors, 1993: 306).

Method of education

Ghazali wrote in countless books on ethics and Sufism about the training, including its methods mainly in this case about three approaches: religious, mystical and Greek. The religious and mystical approach are only about adults while the Greek approach is addressed only to the education of young children. Ghazali proposed methods are numerous and referred to here are some of them:

\section{TRAINING}

This method that is the most comprehensive and the most common method in Ghazali educational system provide a technique to increase scientific ability of the individual and its educational value lies in higher levels (Rafiei, 2002: 277-278).

\section{ACTION AGAINST OR IMPOSITION OF SELF}

In this method, knowledge and emotion and proper behavior are imposed on soul of trainee and tolerating such difficulty, the current situation is gradually replaced by the ideal situation (rafiei, 2002: 283).

\section{REPELLING WORSE WITH BAD}

This method is based on the principle of graduation and is based on the premise that trainee doesn't want to suddenly shift to a certain cognitive or emotional or behavioral characteristics. Ghazali propose that for training such people a few steps from easy to difficult be taken by trainee instead of sudden change from current to ideal status (Qazali, 1985: 26).

\section{ENJOINMENT OF GOOD AND PROHIBITION OF BAD}

In the eyes of Ghazali, the pillar of religion and the most important thing that God has sent by his messengers is enjoinment of good and prohibition of bad. And if this is not done, nothing but ruin will result (Ghazali, 1985: 306). 


\section{OBSERVATION AND THINKING}

One way of cognitive development is by thinking. It is true that thinking originally and directly affects human cognitive domains, but since cognitive domain affects emotional aspects of the behavioral, with the transformation and growth of cognitive domain, emotional and behavioral aspect of human personality are also transformed (Ghazali, 1985: 426-427).

According to divine learning (through depth understanding) being seen as a way of knowledge by Ghazali, he proposed jihad as the best way of learning, which required detachment from the world (Dagh, 1990: 38).

Ghazali argued by punishment, a behavior can be punished or eliminated. Punishment usually raise negative emotions in people and causes them to be worried and upset. A team of psychologists argue that punishment should in no way be implemented and its implementation must be avoided as much as possible. Although in some cases, punishment reduce or eliminate inappropriate behavior, but in most cases, after removal of punishment, inappropriate behavior appears again. It is keeping out of reach of children the positive amplifiers as well. Punishment results in the emergence of negative emotions like hatred and fear in children (Shafiabadi, 1994: 183).

About the relationship between fear and punishment, Ghazali described punishment style as follows: fear has three degrees: weak, moderate and strong; because the good one is moderate one, and weak is useless, like women's act, and strong one is hopeless and results in illness and death and unconsciousness. Fear is not good itself unlike unity, knowledge and kindness, which is why it is not an attribute of the God Almighty, but without fear never comes in absence of ignorance and frustration, besides fear is like cool whip that should be moderate, otherwise it is not working well. If it is moderate, it will bring about obedience and prevents sin. In his guidelines to teachers, he said, teacher shall punish the children by encouragement and warning rather than corporeal punishment (Attaran, 1987: 73).

\section{PLAN OR CONTENT OF EDUCATION}

In training, the trainee should be helped to move from early stage in the course of time, where the behavior is crude and inadequate and involuntary, toward a state of perfection as ordained in His creation and in that case, as in any situation, his behavior moves from a state of weakness to the ability and independence in relatively slow manner and usually there is no sudden change in no time (Shokuhi, 1994: 112).

In The recommendations to teachers, Koran is the basis of education. Imam Mohammad Ghazali says about it: when you are in high school (school), the Koran must be taught (Attaran, 1987: 120).

Ghazali believes that in addition to the acquired sciences, there should be in educational programs natural and spiritual perfection and they are necessary for coach. He believed that as mentor is required for these science and knowledge, for perfection of the human being, teacher and guidance is also necessary for moral and spiritual perfection (Al-Ghazali, 1992: 298).

Here is the most important issues considered by Imam Mohammad Ghazali in educational content:

In the field of natural sciences, Ghazali was among those who strongly disagreed with the natural sciences and banned its study by people. He wrote about physics, "fourth is physics, and some of it is against religion; this is right and it is ignorance, not the knowledge to be include in all classes sciences, and some are discussions of attributes of objects and their properties and their transformations; however, medicine is concerned with health and illness while physics focuses on moving and changing of objects, and medicine is better as it is needed, while physics is not. Dr. Ahovani believes that lack of attention to natural science by Muslims is due to intensity of their zeal for religion and fear of distraction and believes Muslims avoided it for the safety of religion and faith took away from exploring the nature (Attaran, 1987: 129). 
As for poem, gazelle focused on delight of children from music, like Plato, he believed that Songs recall the spirit associated with the object before it is familiar. Ghazali believed that music and singing is allowed, while some of the scientists of that era hated music and singing intensely. Ghazali said, citing historical reasons: In Islam, singing was not prohibited at any time and the Prophet (PBUH) who had a good voice to sing to encourage those who were digging ditches (Thomas, 1985: 633). Ghazali in the Law discussed poems and prevented addressing some of the poems. For this reason, Ghazali emphasis has been more on the lyrical content.

\section{TEACHING METHOD}

According to Ghazali, after experience and intuition, thinking leads to will. He wrote, "We are what we know". This is contrary to Descartes's words cogito ergo sum. Descartes gave precedence to thinking over the existence of the God, and accessed his existence through thinking while Ghazali believed in spiritual experience which leads to knowledge and the next state, namely selection, and existence of the God and his being and because he didn't question his being, he believed existence of god was known in joy, luck and connection as three experiential, positivist and objective stages of the human union with himself, namely, the discovery the inner soul that forms character of each person (Ghazali, 1987: 10).

He change way of teaching and learning that was common in his time; he criticized useless science, which stimulate and arouse a sense of zeal and selfishness and technique debate and argument common at his time information, saying that if it was a way of showing off and overcoming, it would be the ugliest and worst things (Homaei, 1989: 398 ).

His idea was that the child must receive education of children so that faculties of reason and reasoning would be strengthened, rather than memorizing information, however, he believed reason was necessary for continuation of human life and leadership. Ghazali believed that memories would not help the development of science and what helped science was strengthening of reason and innovative power (Thomas, 1985: 633).

\section{EDUCATION IN WEST}

Almost all famous western philosophers have written on education. Plato saw education as a part of policy. Following Plato, St. Augustine was interested to know how we learn and how teachers teach. Thomas Aquinas at the University of Paris had been working actively in teacher training, especially offered in theory of Thomism and neo-Thomism. And his name is well known. Enlightenment thinkers such as Rousseau and Locke provided the classics in the field of education. Rousseau wrote material about the youth, mostly criticizing the activities of his time in training. Locke's ideas in the field of education, child-rearing and education concepts revolutionized our conceptions. Immanuel Kant (German philosopher) gave important speeches in the field of educational science to the teachers (Zamiri, 1995: 102).

\section{OBJECTIVES OF EDUCATION}

For Plato, the main objective of the education that he believed was "the most important imperative" was to discover the outstanding talents and prepare them for leadership in an ideal society, which means a society based on justice and wisdom. This goal as education of elites involves achieving other goals, most important of which is discovery of talent and natural ability in people, irrespective of their class status, as well as raising them to achieve the objectives of political and social life. The main objective, according to Plato, was achieving an orderly and fair society. Therefore, in the first place, he focused on training of outstanding owners who had the ability to assume leadership positions in security plans in community.

For other people, Plato believed that the minimum training was enough for doing assignments and sometimes he even opposed communication of knowledge to the public and for this reason, some scholars consider educational philosophy of Plato as being class-based, because his belief results in gradual increase of the class gap, which in turn prepares ground for tyranny in which a small group of elites dominates the majority public (Kardan, 2009). 
In order to plan and articulate explicit goals education in Plato's view, these objectives are divided into individual goals and social goals of education. Educational individual goals are divided into physical (physical education), taste goals (artistic), the ethical (moral education) and rational goals.

Education was defined by Plato as bodily and mental education. Education and training of bodies realizes through nutrition and exercise and education of mind through music (harmony).

A: The physical purpose (physical education) starts with play according to Plato. Games according to Plato are not only entertainment but also game a role of education. This is a Plato's invention in education. He wants children get used to collective life in society and live in an unchanging society through the game. Sports are more than physical exercise and music is more than what we understand of music. These educate and train body and mind as a foundation that later provides the basis of rational life. They should prepare the whole personality of a person in the field of realization of "speaking well and subsequently, good compatibility and optimal honor and victory, and good harmony" (Mirzamohammadi, 2002).

(B) The taste purpose (artistic) of education: Plato believed that the soul should be led towards truth and beauty and harmony. The soul that lacks a taste for good and beautiful and true joy remains deprived of education and its essence. Much of artistic education is according Plato the music. Other parts include language that is divided into poetry and stories and songs. Plato was the first mentor that found out about the impact of the music. He believes that music would be the beauty and harmony of spirit and passion for beauty and loathing of everything that is bad and the ugly in human circumstances. Plato considered in Laws the "harmless pleasure" and with the greatest confidence stressed the educational and moral responsibility, i.e., feature of pleasure (coupleston, 2007).

The rational goal of education: Plato's early education ends with sports and music at which stage a person becomes capable of intellectual training that is higher stage of education. The courses such as calculus, geometry, astronomy are taught in this stage. Of mathematical branches, geometry was most favored by him. By passing these courses, one is prepared for the last period of higher education that is dialectical philosophy. Scientific education age between 22 and 53 years. At this point, the person has ability to think abstractly. At higher level of rational education, person reaches "idea" that is the pinnacle of Plato's education (mirzamohammadi, 2002).

\section{PRINCIPLES OF EDUCATION}

Plato believed in the importance of education of scholars and philosophers to enable them to take control of the government and guide society. When visiting Egypt in 399 BC, Plato was influenced by the fact that priests from educated class ruled people and illiterate farmers by claiming that they were given that power by God. This observation influenced his later ideas about "good republic" (Will Durant, 2013: 16); Plato later wrote, "If a society becomes ill, should not there be guidance for those looking for the best and wisest people? (Nicholas Papa, 2012: 64); finding the most talented people and preparing them for the ruling in favor of the public constituted Plato's political philosophy (Will Durant, 2013: 24).

According to Plato, human nature is standing behind political decisions, "Every state is like its people"; If a government is so, it is because the people are so, as long as there are not good people, we should not expected to have a good government (Nicholas Papa, 2012: 71); rule of philosophers and thinkers Plato believed was the ideal state because until wise people become king and wisdom and politics gather together, people will not see nothing but miseries and misfortunes (Nicholas Papa, 2012: 93).

\section{CURRICULUM}

Plato's dominant approach in education was artistic and aesthetic way. Plato believed that psychology should be pushed toward truth and beauty and harmony. The soul that lacks good and beautiful and true joy is deprived of the education. Both thinkers also emphasized the role of habit, especially in the early years of their education. Children's mental training also begins with music and storytelling by mothers (Kardan, 2009). 
Plato believed that both music and sports were means of nurturing the soul. He wrote in Republic, "Music and sports exist to nurture the soul and the body (Plato, 1995).

The term gymnastics in the sense that Plato intends includes physical education, both as sport and nutrition. The main purpose of physical education is creating physical health as the goal of teaching music is moderation and harmony of the soul (foster, 2010).

The book History of Political Philosophy of the West reads, "The main objective is ensuring healthy body, but Plato knew that because the mental and physical health are linked, he attached more importance of education of the body. In addition, his plan for education aimed at development of the spirit and courage of those were to be workers or members of the military aristocracy and music education was rather related to poetry and literature than musical instruments (Alam, 2002).

Plato's proposed curriculum was to accustom children to play, develop physical strength, and to teach reading and writing and military training, and to teach philosophy and dialectics and literary content.

\section{TEACHING METHOD}

According to Plato, the teaching methods or education method is dialogue method and its method a method through which man learns how to start from what is perceived towards the spiritual world and thus how to go from the scattered and visible work to the world that can only be thought of (kardan, 2009). Imitating the good example also forms part of the training method. The students take valuable lessons based good models drawn from history, literature, religion and philosophy and biography. They are urged to study the model so that the person in question taken as a manifestation of the value. The teacher is also continuous model meaning that he is the integral representation of the highest cultural values. However, teachers should be elected based on competence in the subject matter and technical education to deserve to be followed as role model by students and should be tasteful in aesthetics. Students follow him through the absorption and digestion of his value system and his role as ethical role model in their lives. Following other is not imitating others, but is good in human life (Gotek, 2001).

Shim concluded that Plato considered teaching as guide to objective knowledge through argumentative understanding of the causes. It seems that Plato intended to show difference between conditions of a well-educated and an illiterate person. It can be said that he did so by providing allegory of the cave in which a person experienced gradual changes of his views (shim, 2008).

\section{DISCUSSION AND CONCLUSION}

For Ghazali training was managing self through the balance of the forces and trends through knowledge, for him, education's purpose was to feed soul and conscience of man toward truth and achieving human and divine revelation. Ghazali was experts in the selection of aim of education and insisted on getting to the facts. Achieving the will through meditation or sharing of experience and intuition, nurturing reason were Ghazali educational method, in procedure of training, he invited coaches and trainers not to use the theory of corporal punishment of children and for play, he didn't pay enough attention to its role in education; he saw play it just as refreshment. Ghazali, in discussions of morality, noted ethics variability and refining of instincts and he and considered the Prophets (peace be upon them) as best moral example; Ghazali believed perfect training realized in the care of the self and reaching the ideal of moderation and virtue, at the same time as seeing nurturing of the child's body as requirement of such perfection and focused on them in his works such as Ihya' and Kimia. However, his educational views on aims, method, organization and curriculum are reflected in Nasiha al-Muluk ayuha al-walad, al-adab fi al-din wa fatiha al-ulum.

Comments on training by this divine-human great coach are based on two important three pillars of value-esteem, ethics and science and after nine centuries, they still largely form bases of theoretical and practical training and training officers should study great thinker's ideas. Thinker who noted pure nature of child five centuries before Rousseau did.

It can be concluded that Plato's definition or definitions of education are the sources of new ideas for centuries and even contemporary philosophers (like Rousseau and Dewey) because of precedence over other theories but the problem with Plato's view is that he failed to provide a comprehensive definition of the phenomenon, and under influence of his time, he believed in class education, namely, for him, 
the main goal of education was to get involved in political activities and to create effective political persons.

Plato attached essential importance to the raw nature that is a constant value and believe education was only for privileged class while believing that other classes didn't need no further education beyond spontaneous family and social effects.

Teachers who wish to become proficient in their jobs really should turn their attention to everyday affairs and details. Every teacher knows that education is a powerful tool for shaping individual lives and social system. When the teacher reflects his role, he leaves his concern about the practical things that have practical urgency and thinks about theories on which training activity is based in terms of consistency and durability. Since teaching is a moral activity, it requires careful integration in terms of theory and practice. Theory without practice is inadequate and practice without theoretical guidance does not succeed. In fact, teaching have effects beyond the immediate effects of the training events. The way students are treated by teachers depends on latter's perception of human nature. When the teacher reflects on the concept of reality and the nature of the human and society, the latter actually reflects on education philosophically. Philosophers theorize about the facts, and in this regard, epistemology is one of the fundamental issues. In fact, epistemology is vital for educators, and is closely related to teaching and learning (Gotek, 2001).

To Plato:

1. Education should be compulsory for children.

2. Men and women should enjoy the same education.

3. Culture and education should be at the expense of the state and for all people, whether rich or poor, boy or girl.

4. Plato emphasized the importance of pre-birth and 5 first years of life in terms of formation of character.

5. Community is place of attaining salvation and prosperity.

6. The purpose of education is to achieve the good idea.

To sum up, it can be said that Plato gives emphasis to training in society despite the importance he attached to the individual. Under the political philosophy of Plato, the community is place of attaining perfection, so training for Plato was a collective and social thing. For Plato, the ultimate goal of education is education of citizens who are best capable of fulfilling their social tasks. Plato also considered purpose of human existence to be achievement moral virtues only through education and gaining a true understanding. Plato based realization of his ideal city - justice - on education. $\mathrm{He}$ suggests a society that is more ideal than real, it is a thing of the heaven rather than the earth.

\section{REFERENCES}

Alam A, 2002, history of political philosophy of west, Tehran, ministry of foreign Affair institution press, $360 \mathrm{p}$.

Attaran, M. (1987). Great Muslim mentors' views about the upbringing of children, Tehran: Ministry of education Press.

Buber, and Freire. Teaching and Teacher Education, 515-535, available from: http://www.elsivier.com/locate/Tate.

Couplestone, F, 2007, history of Greek and roman philosophy, volume 1, elmi va farhngi publication, 600 pages.

Durant, W. (2013). History of Philosophy, Trans. A. Zaryab Khoei, Tehran: Ketab Sabz.

Ebrahimzadeh, I. (2004). Philosophy of education, Tehran: Payame Noor University Press.

Foster M, 2010, gods of political the ought, $7^{\text {th }}$ edition, elmi va farhangi publication company, $602 \mathrm{p}$, Persian.

Ghazzali, Imam Muhammad (1992). The alchemy of happiness, trans. A. Aram, Tehran: Ganjineh.

Group authors (1993). Education's philosophy, Tehran: SAMT.

Homaei, J. (1963). On Ghazali, Tehran, Foroughi Bookstore.

Homaei, J. (1989). On Ghazali, $3^{\text {rd }}$ ed., Tehran: Homa. 
Kardan. A, 2009, journey of educative votes in west, $4^{\text {th }}$ edition, tehren, samt publication, 288 pages, pershian.

Makarem Shirazi, N. (1983). Tafsir Nimunah, Tehran: Dar al-Kitab al-Islamiyah.

Mirzamohammadi, M, 2002, a comparative study of education goals from plato's and freebie's view, journal of psychologies and educational science, 32 nd years, No 2, Persian.

Naghibzadeh, M. (1995). Philosophy of education, Tehran: Tahoori.

Naghibzadeh, A. (2009). A look at the philosophy of education, Tehran: Tahuri.

Pakseresht, M.J. (2001). Philosophy of education in educational science: nature and its scope, Tehran:

SAMT.

Pappas, N. (2012). Plato's Republic, Trans. B. Sabzi, Tehran: Padineh.

Plato, 1995, the republice, Tehran, elmi va farhangi publication company, $648 \mathrm{p}$, Persian.

Rafiei, B. (2002). Views of Muslim scholars in education and bases, Vol. III, Tehran: SAMT.

Seif, A.A. (2005). Educational psychology, Tehran: Agah.

Shafiabadi, A. (1994). Technology of upbringing of children, $6^{\text {th }}$ ed., Tehran: Chehr.

Shim S.H, 2008, a philosophical Investigation of the role of teachers, a synthesis of Plato, Confucius, Shokuhi, G. (1994). Education and its processes, Mashhad: Astan Quds Razavi.

Tabatabaei, Seyed Mohammad Hossein (1984). Trans. S.M.B. Mousavi Hamedan, Qom: Islamic Publications Office.

Thomas, E. (n.d.). Ghazali in Baghdad, trans. Z. Mansour, $2^{\text {nd }}$ ed., Tehran: Zarrin.

Zamiri, A. (1995). Education, Shiraz: Rahgosha. 